PERHIASAN KALIGRAFI SECARA FUNGSI DAN ESTETIKA

Ramadhani Kurniawan

Pascasarjana ISI Yogyakarta

Email: rama84art@yahoo.co.id

\title{
Abstrak
}

Tujuan pembahasan ini adalah mendeskripsikan tema penciptaan proses visualisasi teknik dan bentuk perhiasan kaligrafi secara fungsi dan estetika. Metode yang digunakan dalam penciptaan perhiasan adalah metode eksplorasi, yaitu mengolah dan menjelajahi bentuk yang sudah ada dan dikembangkan lagi, kemudian dilakukan observasi melalui media elektronik dan cetak atau kondisi sosial yang ada di lingkungan sekitar. Metode eksperimen dilakukan untuk menciptakan bentuk kaligrafi yang sesuai dengan ide serta pengembangan teknik dalam membuat perhiasan.

Hasil dari pembahasan dapat disimpulkan sebagai berikut: (1) Tema perhiasan kaligrafi secara fungsi dan estetika lebih menonjolkan pada sisi keislaman yang menginspirasi pada Asmaul-Husna, yaitu sifat-sifat Allah, (2) proses visualisasi perhiasan dikerjakan dengan teknik kerawang, patri, dan cor dengan menggunakan bahan logam lunak, seperti perak, alumunium, tembaga, kuningan dan peuter, dengan kecenderungan warna logam yang ditonjolkan, (3) bentuk atau visualisasi perhiasan adalah penggambaran dari kaligrafi (khat) yang dijadikan sebagai pedoman dalam pembuatan perhiasan, seperti kalung dan cincin. Karya yang dikerjakan 10 perhiasan dengan berat yang tidak sama, yaitucincin "Al-Musawwir" berat 5,9 gr, cincin "Al-Majid" berat 19,4 gr, cincin "Al-Haqq" berat 4,2 gr, kalung "Al-Lathif” berat 60 gr, kalung "Al-Wahid” berat 42 gr, kalung "An-Nur" berat 20 gr, kalung "Adz-Zahir" berat 45 gr,kalung "Al-Musawwir" berat 57,4 gr, kalung “Al-Qowiyy” berat 36,5 gr, kalung “Al-Jabbar” berat 25 gr

Kata kunci: Perhiasan, kaligrafi, fungsi dan estetika

\section{PERHIASAN KALIGRAFI SECARA FUNGSI DAN ESTETIKA}

\section{Abstract}

The aim of this paper is to describe the theme of technique creation process and the form of calligraphy jewelry by its function and aesthetic values.

The method used in creating the jewelry is exploration method; they are cultivating and exploring the existing forms and developing them, and then doing observation through electronic and printed media or the social condition around. 
Experiment method was used to be able to create the calligraphic forms based on the ideas and techniques developed in making jewelry.

The results of this study show that (1) calligraphic jewelry, in terms of functions and aesthetic themes, emphasizes the islamic sides that are inspired from Asmaul Husma, Allah's nature; (2) the visualization process of this jewelry is conducted through filigree, solder, and cast techniques by using soft meta materials such as silver, aluminum, copper, brass and pewter, with metallic color trends which are highlighted; (3) the jewelry forms and vizualization are the description of the calligraphy (khat) as sources of inspiration in making jewelry such as necklace and ring. The works done are 10 jewelry in different weights: "AlMusawwir" ring, with 5.9 gm wight; "Al-Majid" ring, with 19.4 gm weight; "AlHaqq" ring, with 4.2 gm weight; "Al-Lathif" necklace, with 60 gm weight; "AlWahid" necklace, with 42 gm weight; "An-Nur" necklce, with 20 gm weight; "Adz-Zahir" necklace, with 45 gm weight; "Al-Musawwir" necklace, with 57.4 gm weight; "Al-Qowiyy" necklace, with 36.5 gm weight; and "Al-Jabbar" necklace, with 25 gm weight.

Keywords : jewelry, calligraphic, function and aesthetic.

\section{PENDAHULUAN}

Indonesia adalah negara yang mayoritas penduduknya Islam, bahkan terbesar di dunia. Negeri ini kaya akan sumber daya alam dan seni yang indah, seperti seni kaligrafi Islam. Jenis seni ini berbentuk tulisan indah yang menyimpan makna dan filosofis tersendiri dalam menyingkap nilai keislaman. Kaligrafi Islam memberikan kontribusi yang cukup besar dalam kehidupan sehari-hari, yakni dapat menenangkan hati dan jiwa (dalam perspektif pribadi), karena didalamnya terdapat makna keilahian yang baik dan memiliki nilai keindahan. Disamping itu, seni kaligrafi dapat dijadikan alternatif media dakwah di tengah-tengah masyarakat yang heterogen/plural. Kesadaran ini didasari

Ki Hadjar Dewantoro mengatakan bahwa seni merupakan hasil perbuata manusia yang timbul dari perasaannya dan bersifat indah, hingga dapat menggerakkan jiwa perasaan manusia (Sudarmaji, 1979: 6). Oleh Sebab itu, sen dapat dikatakan pula sebagai hasil ekspresi individual.Karya seni juga merupakan bahasa ungkap (melalui media gerak, suara, atau pun rupa) dari interpretasi seorang seniman terhadap objek atau masalah di sekitar lingkungan kehidupannya, yang mampu menggugah pikiran, perasaan/emosi, menimbulkan daya kreasi kua untuk dimanifestasikan dan dikomunikasikan melalui media karya seni. Dalam ha ini, maka terjadi komunikasi perasaan seorang (seniman) dengan orang lain diluar dirinya.
Sebagai makhluk individu, seniman memiliki kebebasan mutlak untuk mencurahkan isi pikiran, perasaan dan kreativitasnya dalam proses penciptaan karya. Namun, sebagai makhluk sosial yang hidup di tengah-tengah masyarakat global, tidak terhindarkan bahwa seniman terikat pula oleh norma-norma budaya yang melingkupi kehidupannya. Hal ini sejalan dengan yang disampaikan Soedarso (1990: 56) bahwa suatu hasil seni selain merefleksikan diri seniman sebagai penciptanya juga merefleksikan lingkungan (bahkan diri seniman itu pun terkena pengaruh lingkungannya).Lingkungan ini dapat berwujud alam sekitar maupun masyarakat sekitar.

Sebuah pesan spiritual yang dapat menggugah hati setiap insan yang mendengarkan, dapat menjadi contoh dalam memberikan pelajaran yang berharga, ini dapat diawali dalam mewujudkan suatu karya seni. Bentuk lahiriah suatu hasil seni adalah wujud yang berisi, menimbulkan rasa kagum dan pesona. Suatu wujud seni dikatakan bermutu jika wujud itu dapat memperlihatkan keindahan serta berisi pesan yang dapat memberitahukan kepada orang lain. Faktor lingkungan yang mempengaruhi kekaryaan, menjembatani seorang seniman dalam berimprovisasi, baik dari segi bentuk, teknik, maupun eksplorasi bahan, tentunya yang berhubungan dengan visual, tidak terlepas dari bentukbentuk yang sudah ada.

Kaligrafi yang diambil dari kata lain "kalios" yang berarti indah, sedangkan "graph" yang berarti tulisan atau aksara arti seutuhnya. Kaligrafi adalah kepandaian seseorang dalam menulis elok atau tulisan elok yang mengikuti kaidah estetis/keindahan pada umumnya. Bahasa Arab sendiri menyebutnya khat yang berarti garis atau tulisan indah (Sirojuddin, 1992: 3).Bentuk visual kaligrafi yang menjadi produk perhiasan, menekankan pada Asmaul-Husna. Menurut Ali(2004: 33), Asmaul-Husna merupakan nama-nama Allah yang baik, yang berjumlah 99 .

Dorongan untuk membuat perhiasan kaligrafi dikarenakan penulis sering bermain dilingkungan kerajinan perhiasan, seperti Kotagede Yogyakarta. Hal inilah yang menginspirasi untuk berinovasi dalam menciptakan karya seni. Kerajinan perhiasan mengandung unsur kreativitas alternatif. Ia merupakan kerajinan dihasilkan melalui keterampilan tangan. Umumnya, barang kerajinan banyak dikaitkan dengan unsur seni yang disebut seni kerajinan. Seni kerajinan adalah implementasi dari seni kriya yang telah diproduksi secara massal (mass product). Produk massal tersebut dilakukan oleh pengrajin (Raharjo, 2011: 16-17).

\section{PEMBAHASAN}

\section{Perhiasan}

Sejak zaman dulu orang telah memperindah diri dengan berbagai pernakpernik untuk kecantikan dan keindahan. Perhiasan adalah hasil kerajinan logam 
yang mempunyai fungsi sebagai pelengkap tata busana benda-benda hasil budaya manusia yang digunakan sebagai hiasan untuk memperindah tampilan (Sunaryo, 1982: 203). Perhiasan diperuntukkan bagi para raja dan ratu. Dikawasan lain, keberadaan perhiasan tidak saja dipakai untuk acara-acara tertentu, ia juga memiliki daya saing yang tinggi. Adanya desain yang menarik dan memiliki ciri khas tertentu dapat memberikan pengaruh besar terhadap kemajuan dunia perhiasan.

Karya perhiasan kaligrafi ini terdiri atas jenis logam, yaitu pertama, logam non ferro (logam lunak), seperti perak, tembaga, alumunium, kuningan dan peute dengan teknik patri, kerawang, dan kedua, cor logam. Untuk pengerjaan satu item cincin dan kalung dengan teknik patri dibutuhkan waktu dua minggu, kemudian teknik cor membutuhkan waktu satu minggu dengan pembuatan model dari gip dan lilin wash sampai jadi karya produk.

Visual dalam karya ini adalah perhiasan kaligrafi yang menjadi objek utama. Dengan penggambaran sebagai elemen pendukung yang bertujuan untuk mengaitkanya pada tema, sehingga melahirkan pemaknaan baru yang lebih luas dan longgar untuk diinterpretasikan. Kemudian sebelum proses perwujudan terlebih dahulu dilakukan pembuatan sketsa dengan mengkomposisikan objek kaligrafi dengan bentuk pendukung lainnya. Sketsa dari kertas menjadi acuan untuk dijadikan model dalam pembuatan pola kaligrafi, pewarnaan, pemasangan batu danfinishing.

Selama proses berlangsung memungkinkan terjadinya perubahan komposisi bentuk dari sketsa awal karena penajaman ide dan gagasan. Pada tekni patri, pemindahan sketsa dilakukan pada plat lalu dipotong sesuai pola kaligrafi. Sementara itu pada teknik cor, pemindahan pola dilakukan dengan model dari gip ke cetakan lilin lalu dicetak dengan gip hingga menjadi cetakan logam. Pola sketsa karya dengan ukuran skala 1:1 atau ukuran sebenarnya, terlihat pada karya cincin, kalung, dan gelang. Bentuk yang hadir dalam perhiasan kaligrafi seperti bentuk konvensional atau eksplorasi bentuk lain menjadikan perhiasan kaligrafi tampak unik dan indah.

Kecenderungan penulis untuk membuat bentuk yang sudah ada dan merevisi bentuk lama ke bentuk baru, sepanjang pengamatan tentang bentuk, karya dibuat dengan kesan natural (alami). Asmaul-Husna, yang menjadi pedoman penulis, dijadikan beberapa item perhiasan. Teknik kerawang, patri, dan cor dikerjakan secara manual dengan teknik tingkat tinggi. Bentuk cincin dan kalung dihadirkan berupa objek, seperti bentuk abstrak, motif mega mendung, geometris, dan spiral.

Sumber visual dari hasil penelusuran di internet tentang perhiasan kaligrafi yang menjadi referensi dalam berkarya seni tampak sebagai berikut.

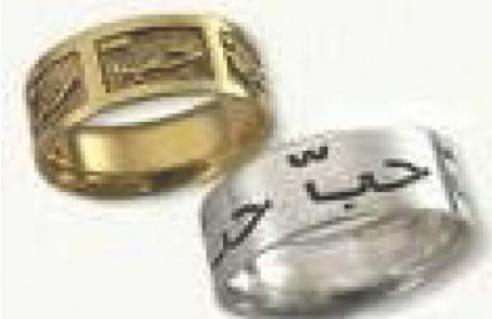

Gambar 1."Cincin". Sumber gambar: www.angelafung.net.

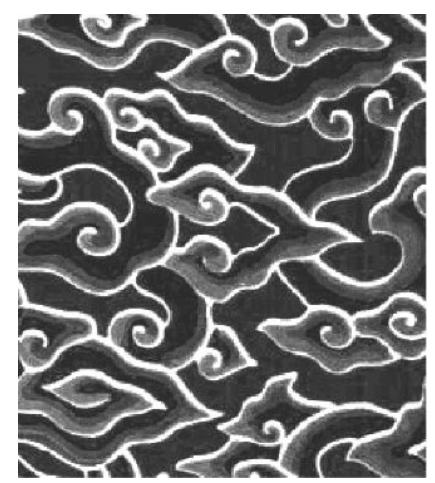

Gambar 2. Motif Ragam Hias Mego-Mendung berasal dari Cirebon, Jawa Barat.

Sumber Gambar: Pepin Van Roojen (Indonesian Ornamental Design)

\section{Metode}

Metode yang digunakan dalam pembuatan karya terdiri atas metode eksplorasi dan metode eksperimen. Metode eksplorasi digunakan untuk menemukan ide secara personal, kemudian digambarkan melalui bentuk-bentuk kaligrafi. Setelah itu, dilakukan observasi melalui media elektronik dan cetak, juga kondisi personal dengan sosial yang ada di lingkungan sekitar. Metode eksperimen dilakukan melalui percobaan-percobaan dalam bereksplorasi dan improvisasi, baik dari segi bentuk maupun bahan yang sesuai dengan ide, serta pengembangannya melalui teknik kerawang, patri dan cor.

Dalam konteks metodologis mengacu pada gagasan bahwa proses penciptaan seni kriya yang disebut sebagai tiga pilar penciptaan karya kriya, seperti eksplorasi, perancangan, dan perwujudan (Gustami, 2004: 31). Eksplorasi berkaitan dengan pengalaman, yakni ekplorasi ide yang dilakakukan dengan mengkaji dan meneliti objek-objek seni secara kreatif dan senantiasa mau melihat 
objek dari berbagai sudut pandang. Metode ini disebut metode brainstorming atau curah pendapat. Brainstorming atau curah pendapat adalah salah satu cara dan proses yang dilakukan oleh sekelompok orang, atau individu, untuk membangkitkan serta memunculkan ide-ide bebas dan liar, untuk nantinya dipilih beberapa yang terbaik, lalu dipilih salah satu diantaranya untuk dijalankan/ diaktualkan (Marianto, 2006: 62).

Dalam melakukan eksplorasi terbuka kepekaan dan sensitivitas terhadap apa yang dilihat maupun dirasakan dan merekamnya dalam pikiran. Eksplorasi menghasilkan endapan material secara abstrak maupun verbal. Material abstrak divisualisasikan dalam material verbal dengan berbagai pengolahan estetis. Dalam hal ini, eksplorasi dilakukan tidak hanya terbatas pada sumber ide saja, tetapi juga pada material yang ada, teknik pengerjaan, dan gaya yang divisualisasikan dalam karya seni.

Pada tahap perancangan hasil rumusan muncul endapan estetis yang begitu kaya dan unik, yang pada akhirnya memunculkan kegelisahan untuk mencurahkan ide tersebut pada media sehingga menjadi sebuah karya seni Berbagai eksperimen terus dilakukan dalam usaha pencarian bentuk, teknik, variasi isian, wujud tampilan, dan sebagainya. Eksperimen awal dilakukan dengan membuat berbagai desain melalui komposisi karya yang bermacam-macam, sehingga memunculkan sebuah komposisi karya yang diinginkan.

Dari pra-desain tersebut, akan dipilih beberapa alternatif yang dianggap tepat dari sisi bentuk, komposisi, dan isiannya. Proses perwujudan memberikan kekuatan yang sama, antara teknik dan ekspresi. Pada prinsipnya, teknik dan ekspresi merupakan satu kesatuan yang secara bersamaan hadir dalam proses penciptaan. Dari berbagai eksperimen yang dilakukan, dapat diulas pembentukan perhiasan kaligrafi dengan berbagai sudut pandang terhadap bentuk tiga dimens yang memerlukan teknik tingkat tinggi (craftsmanship). Gambar di bawah in memperlihatkan bentuk-bentuk yang dihasilkan.

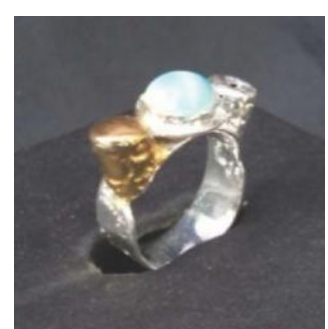

Gambar 3. "Al-Musawwir" cincin dengan teknik patri, berat 5,9 gr, kombinasi bahan perak, kuningan dan batu, finishing dengan sepuh emas. Sumber gambar: Dokumentasi Pribadi, 2007.

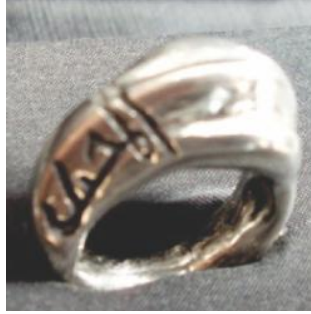

Gambar 4. "Al-Majid", cincin dengan teknik cor, berat 19,4 gr, bahan peuter. Sumber gambar: Dokumentasi Pribadi, 2007

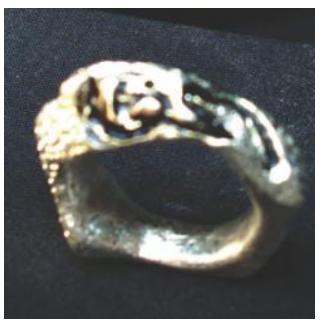

Gambar 5. "Al-Haqq", cincin dengan teknik cor, berat 4,2 gr, bahan Alumunium.

Sumber gambar: Dokumentasi Pribadi, 2007

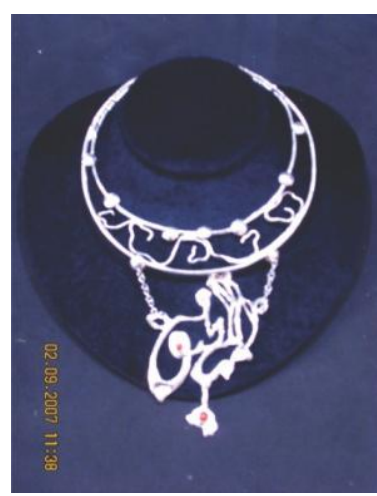

Gambar 6. "Al-Lathif”, kalung dengan teknik patri dan kerawang, berat 60 gr, bahan kuningan, batu, finishing dengan sepuh perak. Sumber Gambar: Dokumentasi Pribasi, 2007. 


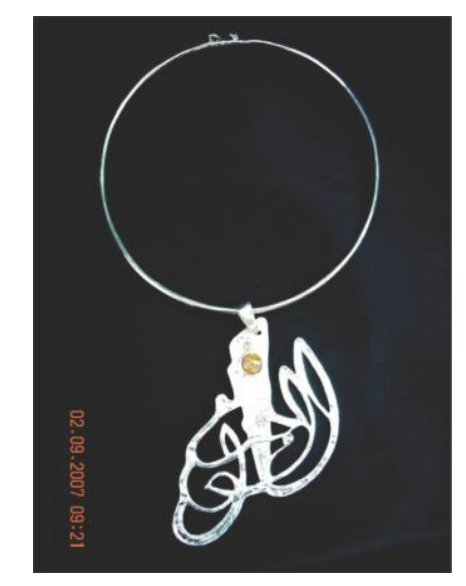

Gambar 7. "Al-Wahid" kalung, teknik patri dan kerawang, berat 42 gr, bahan kuningan, batu, finishing dengan sepuh perak.

Sumber Gambar: Dokumentasi Pribadi, 2007.

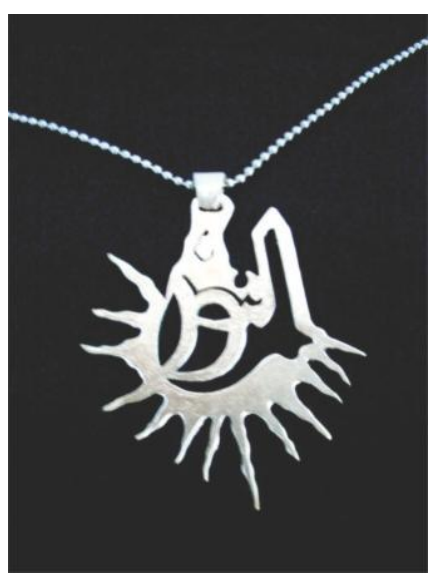

Gambar 8. "An-Nur" kalung, teknik kerawang (melubangi plat), berat 20 gr, bahan plat alumunium

Sumber Gambar: Dokumentasi Pribadi, 2007.

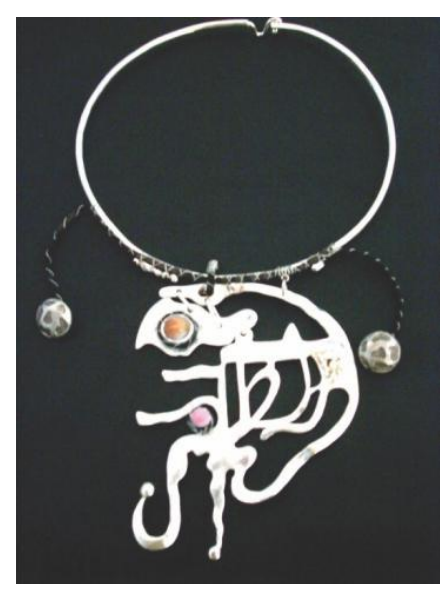

Gambar 9. “Adz-Zahir" kalung, teknik patri dan kerawang, berat 45 gr, bahan kuningan, batu, kulit dan sepuh perak.

Sumber Gambar: Dokumentasi Pribadi, 2007

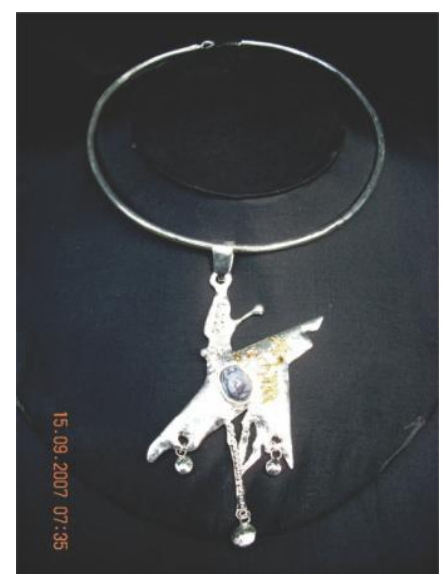

Gambar 10. “Al-Musawwir” kalung, teknik patri dan kerawang, berat 57,4 gr, bahan kuningan dan kombinasi batu, finishing Sleep dan sepuh emas. Sumber Gambar: Dokumentasi Pribadi, 2007. 


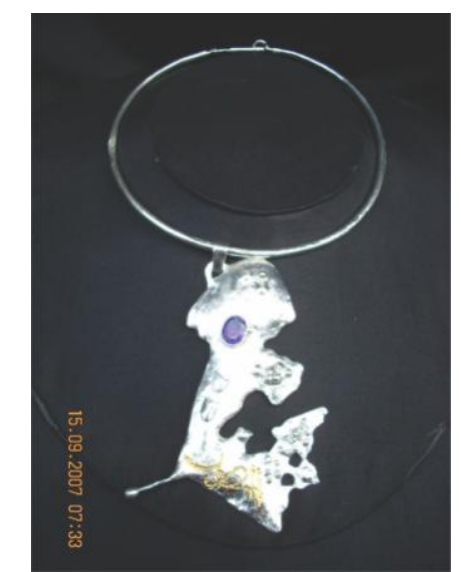

Gambar 11. "Al-Qowiyy” kalung, teknik kerawang dan patri, berat 36,5 gr, bahan tembaga dan kombinasi batu, finishing Sleep dan sepuh emas. Sumber Gambar: Dokumentasi Pribadi, 2007

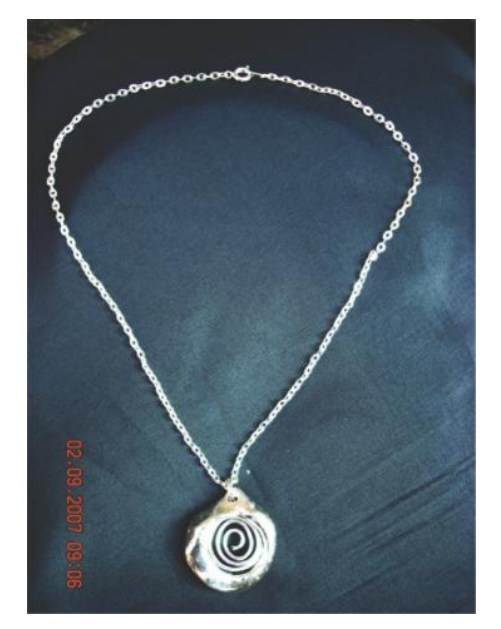

Gambar 12. "Al-Jabbar" kalung, teknik cor dan melilit kawat, berat 25 gr, bahan peuter dan kawat tembaga, finishing Sleep dan Chroom. Sumber Gambar: Dokumentasi Pribadi, 2007.

\section{Fungsi}

Perhiasan merupakan media untuk mempercantik dan memperindah diri, secara fungsi sangat membantu sebagai pelengkap tubuh. Kesan natural menciptakan kepercayaan diri pada seseorang yang memakainya. Dalam karya ini penulis menawarkan nilai ergonomis dengan kenyamanan dan keunikan dari artistik kaligrafi, yang melandasi fungsi ekspresi dan kepuasan batin. Seperti disampaikan Feldman (1990) bahwa fungsi dalam kehidupan modern seperti yang berlangsung pada periode awal sejarahnya seni terus berlangsung untuk memuaskan kebutuhan-kebutuhan individu kita tentang ekspresi pribadi, kebutuhan-kebutuhan sosial kita untuk keperluan display, perayaan dan komunikasi, serta kebutuhan-kebutuhan fisik kita mengenai barang-barang dan bangunan yang bermanfaat.

Melihat perkembangan yang terjadi pada era modern yang begitu pesat, fungsi perhiasan saat ini memberikan nilai dan keragaman untuk dunia kerajinan dan seni perhiasan. Dari keragaman itu penulis mencoba memberikan gagasan bagaimana suatu perhiasan ditinjau dari segi bentuk dan kenyamanan dengan ekspresi kaligrafi yang sangat luwes dan unik.

\section{Estetika}

Dilihat dari sudut pandang estetika, perhiasan kaligrafi menjadi keunikan tersendiri bagi pemakainya, sekaligus memberikan nilai keindahan dengan menelaah makna dibalik kaligrafi itu. Bagi siapa saja yang melihat dan memakai akan terpesona dengan bentuk khat yang sangat indah.

Dari pengalaman estetika penulis, kaligrafi dalam bentuk perhiasan membuat imajinasi semakin luas dan kecintaan terhadap kaligrafi semakin tinggi. Sesungguhnya estetika Islam tampak sangat beragam, seperti yang terdapat pada arsitektur, mesjid dengan motif ornamental, uang logam, dan kombinasi pada tiang bangunan yang mencirikan kaligrafi Islam.

Seni Islam merupakan manifestasi budaya yang bersyarat estetika (priksa, rasa, karsa, intuisi, dan karya). Islam tidak memberikan teori atau ajaran yang rinci tentang seni dan estetika (yang ada tentang etika dan logika). Urusan penciptaan karya seni sebagai produk budaya manusia tidak eksplisit digariskan secara tegas dalam Al-qur'an, karena berkarya seni tergolong urusan dunia yang diatur oleh manusia itu sendiri. Seperti yang diungkapkan oleh Dharsono (2004) bahwa keindahan yang merupakan kecintaan pada manifestasi-manifestasi dari keindahan hakiki, yang disuguhkan oleh seniman (artis) yang sempurna, akan membawa manusia kepada Tuhan, cabang seni yang paling banyak mendapatkan penilaian estetika secara tepat, lebih dari lain-lainnya, di dunia Islam ialah kaligrafi.

\section{Ulasan Karya}

Ada dua hal yang dapat dilakukan dalam mengulas karya, yaitu pertama, berkaitan dengan fisik karya seni yang bersangkutan. Sebagaimana disampaikan Marianto (2006: 73) bahwa terdapat tiga hal utama dalam dimensi fisik karya seni. Ketiganya adalah materi subjek (subject matter), medium, dan bentuk (form). 
Kedua, berkaitan dengan isi (content), berupa makna atau pesan yang ingin disampaikan melalui karya tersebut. Pada karya yang berjudul Al-Musawwir, bermatra tiga dimensional dibentuk dan berdiri diatas dudukan cincin, dengan kombinasi bahan perak dan kuningan, secara keseluruhan bentuk ring cincin seperti mahkota, dan ditengahnya dikombinasi batu berwarna biru. Secara fisik bahan elegan dan menggunakan sepuh emas untuk finishing, ukiran AsmaulHusna pada sepuh emas memberikan nilai religi pada ring yang terlihat kokoh. Terinspirasi dari bentuk-bentuk alam yang telah rusak dengan ketuaannya dengan beragam warna yang menyatu dalam satu kesatuan realitas yang terjadi di zaman sekarang, sebagai refleksi bentuk dengan corak/ragam keutuhan serta kebentukan dari makna spiritual yang didalamnya meliputi pengetahuan yang terinci.

Karya yang berjudul Al-Majid, cincin bermatra tiga dimensional. Berdiri diatas dudukan dengan bentuk yang sederhana, yang diukir Asmul-Husna. Bentuk ini memberikan makna tentang kesederhanaan hidup yang membuat seseorang berfikir untuk kemajuan, mengubah potensi diri. Dengan jalan ini akan tercipta kemuliaan setiap insan yang melakukan perbaikan terhadap dirinya karena Allah azza wa jalla yang lebih mulia di atas segalanya.

Karya berjudul Al-Haqq, cincin yang bermatra tiga dimensional, yang berdiri diatas dudukan yang dirancang khusus untuk keharmonisan dan komposis dengan bentuk tulang yang diberi ukiran Asmaul-Husna.Karya ini berbicara tentang lawan kepalsuan, yaitu kebenaran. Sesuatu yang paling disebut benar adalah eksistensinya sendiri. Ini merupakan pemahaman secara individu yang mengetengahkan kebenaran esensi-Nya yang benar-benar ada dan bukan dengan yang lainnya.

Karya yang berjudul Al-Lathif kalung yang bermatra tiga dimensional. Berdiri diatas dudukan kalung yang dirancang dengan keharmonisan dan komposisi dengan bentuk motif mega mendung. Mega Mendung memaknai dan menggambarkan bentuk awan. Bentuk awan ini disimbolkan ayat-ayat Al-Qur'an yang turun dari langit. Orang patut disebut bijak kalau dia mengetahui seluk-beluk hal yang bermanfaat, karena makna sempurna dari yang penuh kebajikan memadukan kelembutan, bukannya jalan kekerasan. Cara terbaik untuk dapa berbaik hati bagi manusia adalah menarik orang lain untuk menerima kebenaran, dengan sifat-sifat baik-Nya bersikap menyenangkan dan keterbukaan.

Karya yang berjudul $\mathrm{Al}$-Wahid kalung yang bermatra tiga dimensional, yang berdiri diatas dudukan kalung yang dirancang khusus dan mendukung keharmonisan. Komposisi dengan bentuk motif secara keseluruhan dan ditengahnya dikombinasi batu kecintaan dan keutamaan patuh terhadap-Nya sebagai awal dari pengembangan diri karena "Allah sajalah yang mutlak satu" hiasan diri manusia adalah amal dan ketaqwaan-Nya.
Karya yang berjudul An-nur, kalung bermatra tiga dimensional ini diberi dudukan kalung yang dirancang khusus dan mendukung keharmonisan dan komposisi, dengan bentuk cahaya yang memancarkan keseluruh hati dan jiwa, merasa tenang bila keimanan telah terlaksana dan menjadi kebutuhan batin. Semua itu dapat berlaku bagi setiap insan karena Allah bersifat adil dan bijaksana. Bendabenda yang bersifat besar maupun kecil tidak terlepas dari penglihatan-Nya. Cahaya Illahi dapat menerangi setiap dinding-dinding tubuh semua insan. Karya ini terinspirasi ketika cahaya yang selalu menerangi setiap ruang-ruang kehidupan memberikan arti dan makna hidup sebagai keutamaan dan cara pandang terhadap lingkungan sekitar.

Karya yang berjudul Adz-Zahir, kalung yang bermatra tiga dimensional ini diberi dudukan kalung yang dirancang khusus, dan mendukung keharmonisan dan komposisi. Sebagai makhluk Allah dengan segala pemberian-Nya, kita sebagai manusia selalu mencari keinginan yang merasa semua itu dapat dikerjakan dengan cara yang berbeda-beda untuk mencapai sesuatu. Karya yang berjudul $\mathrm{Al}$ Musawwir, kalung yang bermatra tiga dimensional ini diberi dudukan kalung yang dirancang khusus dan mendukung keharmonisan dan komposisi. Alam ini diatur oleh satu individu dan dibentuk dari bagian-bagian yang bekerjasama dalam melaksanakan kewajiban masing-masing. Bentuk alam yang dimaksud merupakan satu kesatuan yang telah muncul dan kerap kali menjadi fenomena alam, yang berproses semenjak dulu sampai sekarang. Kemudian kaitannya dengan manusia yang selalu berupaya untuk membentuk/mengubah perilaku diri dengan kemampuan serta aktivitas sehingga keinginan dari diri sendiri muncul dan berubah.

Karya yang berjudul Al-Qowiy, kalung yang bermatra tiga dimensional ini diberi dudukan kalung yang dirancang khusus dan mendukung keharmonisan dan komposisi. Bentuk geometris dengan rancangan kotak-kotak yang dikombinasi warna emas, dengan ukiran Asmul-Husna, kuat menunjukkan kuasa sempurna sedangkan kokoh menunjukkan intensifikasi kekuatan, memiliki kekuasan penuh dan sempurna kekuasaan-Nya. Karya ini terinspirasi dari bentuk alam, seperti galaksi, planet, dan matahari. Semua itu adalah gambaran tentang kekuasaan Illahi yang tidak terjamah oleh manusia maupun makhluk lain.

Karya yang berjudul Al-Jabbar, kalung yang bermatra tiga dimensional ini diberi dudukan kalung yang dirancang khusus dan mendukung keharmonisan dan komposisi. Dengan bentuk kubah masjid yang dikombinasi kawat yang dibentuk spiral, mengitari siklus hidup, menggambarkan dalam kehidupan beragam corak pilihan-pilihan makna kodrati keimanan yang dapat goyah dan kokoh. 


\section{KESIMPULAN}

Perhiasan merupakan salah satu warisan budaya yang memiliki keunikan dan kekaguman bagi para penggunanya, seperti bentuk perhiasan kaligrafi islam, yang mempunyai makna religi yang sangat tinggi. Sejatinya setiap insan memilik pengaruh terhadap benda-benda yang membuat dirinya merasa percaya diri dengan berekspresi menghiasi diri tentunya dengan hal yang positif. Kaligrafi Islam adalah tulisan indah yang menyimpan makna yang dalam bagi penggunanya.

Sebagai media alternatif dalam berdakwah dengan memberikan pengetahuan keislaman terhadap sesama Muslim, juga memberikan kontribus pemikiran lewat karya perhiasan produk yang dapat digunakan sehari-hari maupun tidak, secara material menggunakan bahan perak, alumunium, tembaga, kuningan dan peuter dengan teknik kerawang, patri dan cor logam. Secara kefungsian dapat digunakan sewaktu-waktu atau pada acara pesta, dan dimungkinkan juga untuk pergelaran fashion show tentunya.

Perhiasan sebagai pelengkap tubuh dalam tubuh, memberikan keluwesan dengan bahasa visual sebagai pengganti makna dasar, ketika hiasan telah menjadi faktor pelengkap, pada karya seni diciptakan sesuatu yang baru dalam membuat inovasi dan kreasi secara estetika serta memiliki muatan. Perhiasan kaligrafi mengacu pada sifat-sifat Allah dengan gaya khat yang sangat khas dalam mengeksplorasi garis, bidang, bentuk, warna, tekstur dan komposisi, dengan susunan yang unik dan menarik. Berikut karya perhiasan yang dikerjakan sebanyak 10 diantaranya dengan berat, yaitu cincin "Al-Musawwir" berat 5,9 gr, cincin "Al-Majid" berat 19,4 gr, cincin "Al-Haqq" berat 4,2 gr, kalung "Al-Lathif" berat 60 gr, kalung "Al-Wahid”, berat 42 gr, kalung "An-Nur" berat 20 gr, kalung "Adz-Zahir" berat 45 gr, kalung "Al-Musawwir" berat 57,4 gr, kalung "AlQowiyy” berat 36,5 gr, kalung “Al-Jabbar” berat 25 gr.

\section{DAFTAR PUSTAKA}

Ali, Muhammad Nur. 2004. Kamus Agama Islam. Annizam: Cirebon. Dharsono,

Sony Kartika. 2004. Pengantar Estetika. Rekayasa Sains: Bandung. Feldman,

Edmund Burke. 1990. Art As Image and Idea. Diterjemahan Gustami Sp. Fakultas Seni Rupa dan Desain, ISI Yogyakarta: Yogyakarta.

Gustami, SP. 2004. Proses Penciptaan Seni Kriya: Untaian Metodologis. Pps ISI Yogyakarta: Yogyakarta.

Marianto, M. Dwi. 2006. Quantum Seni. Dahara Prize: Semarang.

Raharjo, Timbul. 2011. Seni Kriya dan Kerajinan. Program Pasca Sarjana ISI Yogyakarta: Yogyakarta.

Sirojuddin, AR. 1992. Seni Kaligrafi Islam. Rosdakarya: Bandung.
Soedarso, Sp. 1990. Sejarah Perkembangan Seni Rupa Modern. Penerbit Saku Dayar Sana: Yogyakarta.

Sudarmaji. 1979. Dasar-dasar Kritik Seni Rupa. Dinas Museum dan Sejarah Pemerintah DKI: Jakarta.

Sunaryo, Hadi. 1982. Penuntun Praktek Kerajinan Logam. Departemen Pendidikan dan Kebudayaan: Jakarta. 
